\title{
PRIMARY PHYSICAL MECHANISM OF DIFFERENT MAGNETIC FIELDS ACTION ON ROOTS OF SOME PLANTS
}

\author{
N.V. Sheykina ${ }^{1}$, N.I. Bogatina ${ }^{2}$

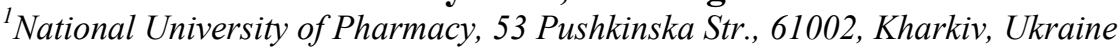 \\ e-mail: sheykina@ukr.net \\ ${ }^{2}$ B. Verkin Institute for Low Temperature Physics \& Engineering of National Academy of Sciences of Ukraine, \\ 47 Nauki Ave., 61102, Kharkiv, Ukraine \\ e-mail:n_bogatina@rambler.ru \\ Submitted January 31, 2017 \\ Accepted October 25, 2017
}

Background: Though the magnetic field action on biological object is proved now by many experiments it cannot be explained. The counterarguments are the small value of magnetic induction, that is effective for static magnetic field and the small value of ions free path length for ion cyclotron resonance presence. Objectives of the article were to generalize all the results that had been obtained before in static, alternative and combined magnetic fields and to explain all results by one and the same primary physical mechanism.

Materials and methods that were used to obtain experimental results were based on the using of well reproducible magnetic conditions. For this purpose 3 lays $\mu$-metal shield and superconductive shield with warm volume were used. The artificial magnetic field was created in the shield. The objects of the investigation were roots of cress, maize and pea. Their gravitropic reaction was studied.

Results and discussion: All experimental results were compared with the theories and calculations maid before and following from the three mechanisms proposed below.

It was shown that there were three physical primary mechanisms that could lead to effect of low frequency alternative and combined magnetic fields and permanent magnetic field on gravitropic reaction in plants. All of them depended on the relative location of roots, gravity and components of permanent and alternative magnetic fields between themselves. The first mechanism is based on the classic model of the rotation of ions in the plane that is perpendicular to the magnetic field direction or precession of magnetic moments round the direction of magnetic field vector. The second mechanism is connected with the piezoelectric properties of starch grain (porous piezoelectricity). This property of starch may create the change in the moving of starch grains in alternative and combined magnetic fields, and even in static one. The third mechanism is caused by the phase transition in water created by weak combined or alternative magnetic fields.

Conclusions: The comparison of effects of these three mechanisms between themselves allowed choosing the most possible one. It was shown that the first mechanism was preferred. Only the first mechanism can explain the dependence of observed effects on magnetic field direction.

KEY WORDS: combined magnetic field; alternative magnetic field; permanent magnetic field; cyclotron frequency of ion; starch grains; piezoelectricity; hydronium; free path of ion.

\author{
ПЕРВИЧНЫЙ ФИЗИЧЕСКИЙ МЕХАНИЗМ ДЕЙСТВИЯ РАЗЛИЧНЫХ МАГНИТНЫХ \\ ПОЛЕЙ НА КОРНИ НЕКОТОРЫХ РАСТЕНИЙ \\ Н.В. Шейкина ${ }^{1}$, Н.И. Богатина ${ }^{2}$ \\ ${ }^{1}$ Национальный фармацевтический университет, ул. Пуикинская 53, 61002, Харьков, Украина \\ ${ }^{2}$ Физико-технический институт низких температур им. Б.И. Веркина НАН Украины, просп. Науки, 47, 61102 \\ Харьков, Украина
}

Актуальность. Действие магнитных полей на биологические объекты в настоящее время доказано множеством экспериментов, однако единого физического механизма, объясняющего магнитные эффекты, до сих пор не существет. Одним из молекулярных механизмов биологического действия переменных магнитных полей может быть ионный циклотронный резонанс. Однако, в таком случае становятся труднообъяснимыми наблюдаемые малая величина магнитной индукции для постоянного магнитного поля и малая длина свободного пробега ионов для комбинированного магнитного поля. 
Цель работы. Целью работы было обобщить собственные результаты, полученные ранее в постоянном, переменном и комбинированном магнитных полях и объяснить их с помощью одного первичного физического механизма.

Материалы и методы. Используемые в работе методы основаны на соблюдении хорошо воспроизводимых магнитных условий. Для этого использовали 3-х слойные пермаллоевые экраны и сверхпроводящий экран с теплым рабочим объемом. Искусственное магнитное поле создавали внутри экранов. Изучалась гравитропическая реакция корней кресс-салата, кукурузы и гороха.

Результаты и обсуждение. Все полученные результаты сравнивались с теориями и расчетами, сделанными ранее, и тремя механизмами, предложенными ниже. Было показано, что существует три первичных физических механизма воздействия постоянного, переменного и комбинированного магнитного поля на гравитропическую реакцию растений. Они зависят от взаимного расположения корней, силы гравитации и взаимного расположения компонент магнитного поля (постоянной и переменной). Первый механизм основан на классической модели вращения ионов в плоскости, перпендикулярной направлению магнитного поля, либо прецессии магнитных моментов вокруг направления вектора магнитного поля. Второй механизм связан с пьезоэлектрическими свойствами крахмальных зерен (пористое пьезоэлектричество). Это свойство крахмала может вызывать изменения движения крахмальных зерен в комбинированном, переменном и даже постоянном магнитном поле. Третий механизм связан с фазовыми переходами в воде, вызванными слабым комбинированным или переменным магнитным полем.

Выводы. Сравнение эффектов, вызванных тремя этими механизмами между собой, позволило выбрать наиболее вероятный механизм. Показано, что первый механизм является наиболее предпочтительным, поскольку он позволяет объяснить зависимость наблюдаемых эффектов от направления магнитного поля.

КЛЮЧЕВЫЕ СЛОВА: комбинированное магнитное поле; переменное магнитное поле; постоянное магнитное поле; циклотронная частота ионов; крахмальные зерна; пьезоэлектричество; ионы $\mathrm{H}_{3} \mathrm{O}^{+}$; длина свободного пробега иона.

\section{ПЕРВІСНИЙ ФІЗИЧНИЙ МЕХАНІЗМ ДІЇ РІЗНИХ МАГНІТНИХ ПОЛІВ НА КОРІННЯ ДЕЯКИХ РОСЛИН Н.В. Шейкіна ${ }^{1}$, Н.І. Богатіна ${ }^{2}$ \\ ${ }^{I}$ Начіональний фармацевтичний університет, вул. Пушкінська 53, 61002, Харків, Україна ${ }^{2}$ Фізико-технічний інститут низьких температур ім. Б.І. Вєркіна НАН України, просп. Науки 47, 61102, Харків, Украӥна}

Актуальність. Дію магнітних полів на біологічні об'єкти на теперішній час доведено великою кількістю експериментів, однак єдиного фізичного механізма, який би пояснював магнітні ефекти, досі не існує. Одним 3 молекулярних механізмів біологічної дії змінних магнітних полів може бути іонний циклотронний резонанс. Однак у цьому випадку важко пояснити малу величину магнітної індукції для постійного магнітного поля і малу довжину вільного перебігу іонів для комбінованого магнітного поля, що спостерігаються.

Мета роботи. Метою роботи було узагальнити власні результати, що були отримані раніше в постійному, змінному і комбінованому магнітних полях та пояснити їх за допомогою одного первинного фізичного механізму.

Матеріали і методи. Застосовані у роботі методи засновані на використанні добре відтворюваних магнітних умов. Для цього використовували 3-х шарові пермаллоєві екрани та надпровідний екран 3 теплим робочим об'ємом. Штучне магнітне поле створювали всередині екранів. Досліджувалась гравітропічна реакція коріння крес-салату, кукурудзи і гороху.

Результати та обговорення. Всі отримані результати порівнювалися з теоріями і розрахунками, які були розроблені раніше, і трьома механізмами, запропонованими нижче. Було показано, що існує три первинних фізичних механізми впливу постійного, змінного та комбінованого магнітного полів на гравітропічну реакцію рослин. Вони залежать від взаємного розташування коренів, сили гравітації і взаємного розташування компонент магнітного поля (постійної та змінної). Перший механізм заснований на класичній моделі обертання іонів в площині, що перпендикулярна напряму магнітного поля, або прецесії магнітних моментів навколо напрямку вектору магнітного поля. Другий механізм пов'язаний 3 п'єзоелектричними властивостями крохмальних зерен (пориста п'єзоелектрика). Ця властивість крохмалю може викликати зміни руху крохмальних зерен в комбінованому, змінному і навіть постійному магнітному полі. Третій механізм пов'язаний з фазовими переходами у воді, що викликані слабким комбінованим або змінним магнітним полем. 
Primary physical mechanism of different magnetic fields action on roots...

Висновки. Порівняння ефектів, викликаних трьома цими механізмами між собою, дозволило вибрати найбільш ймовірний механізм. Показано, що перший механізм є найкращим, оскільки він дозволяє пояснити залежність спостережуваних в магнітному полі ефектів від напряму магнітного поля.

КЛЮЧОВІ СЛОВА: комбіноване магнітне поле; змінне магнітне поле; постійне магнітне поле; циклотронна частота іонів; крохмальні зерна; пориста п'єзоелектрика; іони $\mathrm{H}_{3} \mathrm{O}^{+}$; довжина вільного пробігу іону.

Bogatina N.I. supposed many years ago that the primary mechanism of magnetic field action on biological objects had the physical nature [1]. It was shown in [1] that there were many analogies between the action of magnetic field and gravity. The action of permanent magnetic field and gravitry had the thresholds and their threshold values correlated very well between themselves. These conclusions were made on the base of the experimental works of Bogatina et al. on the observing of the threshold of growing reaction of wheat' coleoptiles and roots [2] and work of Merkis [3] who observed the threshold dependence of gravitropic reaction of roots and coleoptiles of plants on gravity.

In our previous works we obtained the following experimental results.

1. The presence of threshold for gravitropic reaction of plants both in permanent and alternative magnetic field $[4,5]$.

2. The biological effect in combined magnetic field (static magnetic field and collinear to it alternative magnetic field) depended on the direction of roots relatively permanent and alternative magnetic fields and the direction of these fields relatively the gravity force and each other $[6,7,8]$.

3. The observation of negative gravitropic reaction for roots in some cases [9-13].

4. The distribution of amyloplasts and $\mathrm{Ca}^{2+}$ ions in the roots differed from the usual while the negative gravitropic reaction was observed. For small time of treatment in combined magnetic field amyloplasts were located in the center of the cells. For long time they moved to the upper part of the cells. $\mathrm{Ca}^{2+}$ ions moved to the upper part of the cell in contrary its usual movement to the down part $[10,12,13]$.

5. The dependence of biological effect on concentration of $\mathrm{Ca}^{2+}$ ions was not linear [10].

The aim of the work is to compare the experimental results obtained by us before with the new theoretical propositions and accounts supposed by other authors and us and selection of the preferred model.

\section{MAGNETIC AND ELECTROMAGNETIC CONDITIONS}

It is important to notice here that all experimental results we used here to build the model of static, alternative and combined magnetic fields action on biological objects (roots in our case) were obtained under well reproducible magnetic and electromagnetic conditions [4-13]. These conditions were achieved by using two- coated $\mu$-metal shields and superconductive shield with warm volume on the technical base of the Institute for Low Temperature Physics and Engineering of National Academy of Science of Ukraine (Kharkov, Ukraine).

The static and alternative magnetic fields were created artificially by 2 coaxial solenoids in $\mu$-metal shield. The remained magnetic field in $\mu$-metal shield was equal to $20 \mathrm{nT}$. The level of magnetic noise at the frequencies we used was not more than $2 \mathrm{nT} / \mathrm{Hz}^{0.5}$.

For superconductive shield with warm volume the remained magnetic field was equal to 5-7 nT. The static magnetic field was frozen in the work volume by transition the $\mathrm{Pb}$ shield in the superconductive state in external magnetic field from the circular couture, that wasn't located in the bottom part of the shield. The magnetic noise level for superconductive shield was not more than $0.01 \mathrm{nT} / \mathrm{Hz}^{0.5}$.

The alternative magnetic field was created by using of long solenoid. The data in combined magnetic field were obtained for cyclotron frequency of $\mathrm{Ca}^{2+}$ ions. The static 
magnetic field's induction was $8.65 \mu \mathrm{T}$, the alternative magnetic field's amplitude was $15.9 \mu \mathrm{T}$, the frequency of it was equal to $6.85 \mathrm{~Hz}$.

\section{MECHANISM OF MAGNETIC FIELD ACTION}

In [7] we proposed the mechanism of action of permanent magnetic field and combined one. It was based on the results of our experiments of action of both the permanent magnetic field and combined one and the theoretical work of Liboff with coauthors [14].

Here we developed our proposition [7].

In [7] we showed that the absence of permanent magnetic field leaded to the decreasing of any ions stream diameter near the membrane and to the changes of pressure on the membrane. So it might to lead to the shutting of some channels for ions and to the presence of biological effect. The effect had to have the threshold for magnetic inductance value that depended on the minimal distance between the ion's channels.

This model was used recently by Bingi V.N. [15]. The dependence of the probability of biological effect on the magnetic field inductance coincided very well with the obtained by us in $[4,5]$ even in details. (Fig. 1, 2).

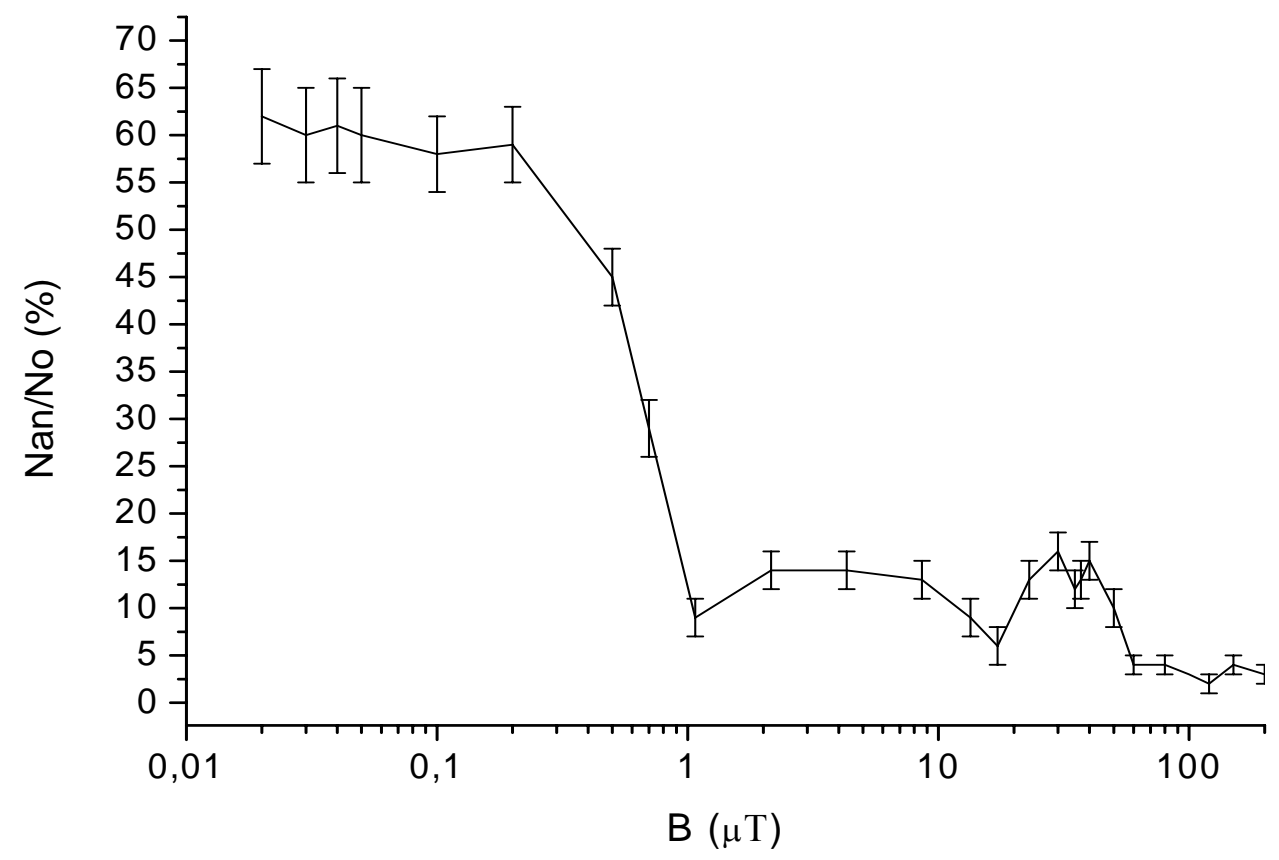

Fig. 1. The dependence of quantity of roots with anomalous gravitropic reaction (that is up and perpendicular to gravity) on the inductance of permanent magnetic field (experimental results [4]).

But we have to notice, that the value of the effect in the experiment was about $60 \%$, while the predicted one was only $15 \%$. The difference might be connected with the difference of the parameters values (here $\alpha$-was the parameter of signal interaction and $\tau$-was the parameter of the thermal interaction). The other reason for the difference was the following. In [15] the averaging was made for all directions of ions, but in our case we had evidently one main direction.

From the comparing of our results with the results of assessments [15] we can obtain besides the threshold value that is equal to $0.1-1 \mu \mathrm{T}$, the time of thermal relaxation for ions. It is of order $10^{-7} \mathrm{~s}$ for electrons, $10^{-3} \mathrm{~s}$ for proton and $10^{-2}-10^{-1} \mathrm{~s}$ for ions. The qualitative accordance between curves on Fig. 1 and Fig. 2 was good. As we noted [7] the effect is more 
Primary physical mechanism of different magnetic fields action on roots...

for directed moving of ions. And it can decrease and even disappear when there was no distinguished direction of ions moving or this direction coincides with the direction of permanent magnetic field. As it was noticed in [15] the biological effect may be much more than the primary probability effect that had been counted.

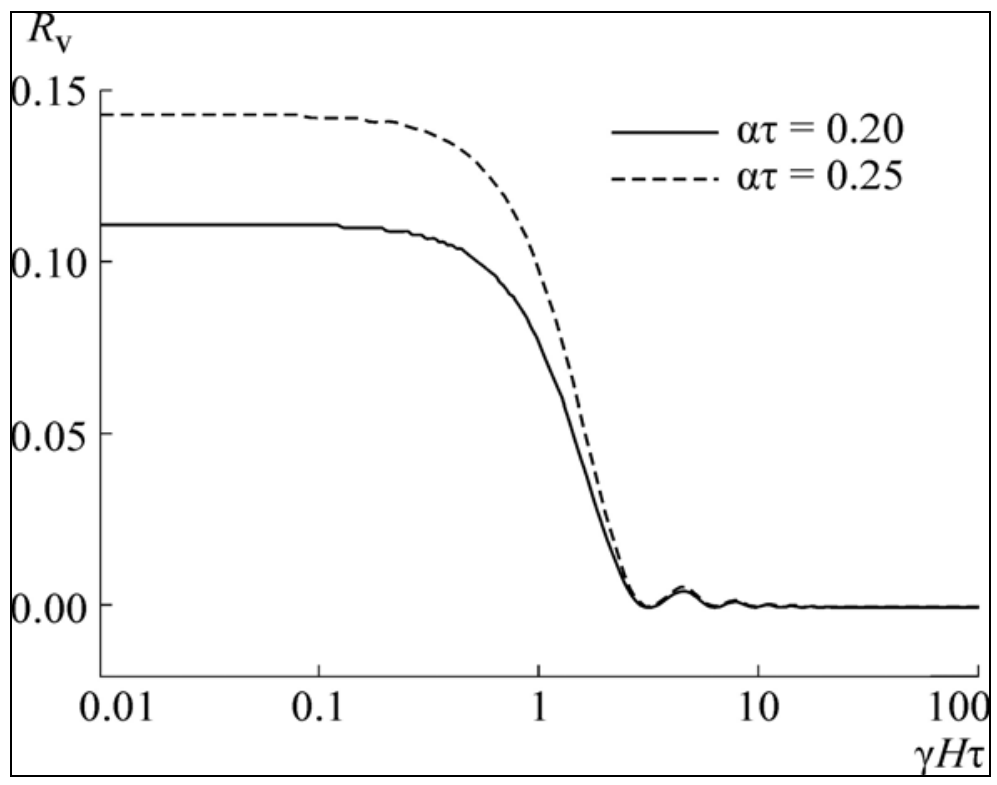

Fig. 2. "Effect of magnetic vacuum" is the increasing of probability of primary reaction caused by the permanent magnetic field decreasing [16] ( $\gamma$ is the gyromagnetic attitude; $\tau$ is the time of thermal relaxation). The probability $\mathrm{R}$ is zero dimensional magnitude and the magnitude $\gamma \mathrm{H} \tau$ is zero dimensional too.

The only criticism that might take place was the big value for thermal relaxation time. It might be got over by the last theory of Del Guidice [16] who noted that adjacent to the membrane in EZ water (the type of water, variously called vicinal, interfacial, and now excluded zone, or E-Z water) the free path's length of ions could be much longer because of the domain structure of the water. This fact was confirmed indirectly by our work on hydronium $[17,18]$ and directly in the work of Liboff [19] they observed the phase transitions in the pure water in combined magnetic field and alternative magnetic field.

The same threshold effect was obtained for alternative magnetic field treatment while the static magnetic field was absent $[5,20]$. We studied the gravitropic reaction of cress roots on time at the amplitudes of alternative magnetic field from $20 \mathrm{nT}$ up to $5 \mu \mathrm{T}$ and wide diapason of frequencies (from parts of $\mathrm{Hz}$ up to $50 \mathrm{~Hz}$ ).[5]. We revealed the presence of the step at the curve of dependence of roots' divergence angle on amplitude of alternative magnetic field. It was located approximately at $2 \mu \mathrm{T}$. At amplitudes less than $0.2 \mu \mathrm{T}$ the gravitropic reaction of cress roots was decreased essentially, but at the amplitudes more than $4 \mu \mathrm{T}$ the gravitropic reaction was usual. So both static and alternative magnetic fields starting from certain magnitude began to influence on the gravitropic reaction of roots. The influence consisted in the essential increase of gravitropic reaction above some amplitude of alternative or static magnetic field. The threshold induction value is more for alternative magnetic field, than for static one. The fact coincides with the accounts [15].

The explaining of the effect is based on two hypotheses. The first one takes in to account membrane electric field and the second one proposes that $\mathrm{Ca}^{2+}$ ions flow by narrow directed stream. 
The roots treated in the alternative magnetic field are present some part of period in the magnetic field that is less than the threshold of static magnetic field. This fact leads to decreasing of gravitropic reaction. When the amplitude of magnetic field becomes more than definite value, the ion's stream widens and captures more channels. So the gravitropic reaction has to increase until the definite limit. The limit is determined by ions' free path length [5, 20].

The effect didn't depend on the frequency while we substitute the permanent magnetic field by the alternative one [15] for the frequencies more than $1 \mathrm{~Hz}$.

In the work [17] we explained the effect of combined magnetic field action by the fact that in combined magnetic field some part of the time our roots were in the magnetic field that was less than the threshold value and it might lead to the essential decreasing of gravitropic reaction. And this model was calculated in the work of Bingi V.N. [15].

As it was shown in [7] all the ions that had velocity non parallel to the magnetic field direction were pressed to the cell membrane (the centrifugal force appeared during the rotation of ions). The induction of combined magnetic field changed from 0 to its maximum value during the period of alternative magnetic field so the pressure on membrane changed from maximum to 0 . The amyloplasts might be carried away by ions stream to the membrane and pressed to membrane. When the inductance became too small and aspired to 0 the amyloplasts might be thrown away from the membrane to the center of the cell or even more to the upper or lowerlaying part of the cell. As the concentration of ions in the lower-laying part of the cell was more than in the upper one due to the gravity, the concentration of amyloplasts in the upper part of the cell might exceed the concentration in the lower-laying part of the cell. All these facts were observed by us in $[10,12,13]$. The maximum effect had to be seen when there was the directed movement of one type of ions and it might be increased by the resonance at cyclotron frequency that coincided with the frequency of the alternative magnetic field. The amyloplasts might even to defense the investigated ions from the collisions with other ions and to increase their free path's length. The ions might be also carried away with the amyloplasts to the upper part of the cell. As the amyloplasts had a big mass compared to the ion's mass the way at which the ion lost its speed also increased when it moved with the amyloplasts. Besides the change of $\mathrm{Ca}^{2+}$ ion concentration might lead to the change of the concentration of auxin ions because $\mathrm{Ca}^{2+}$ ion took part in the process of syntheses of auxin and so to change of gravitropic reaction.

All these considerations might to explain all effects we observed. We can also explain all the results about the dependence of biological effect of the direction of combined magnetic field. The absence of any effect for parallel directions of roots and combined magnetic field may be easily explained. The direction of ions stream didn't change in parallel to its direction magnetic field. The investigation of combined magnetic field influence on the plants roots gravitropic reaction was studied in details before [6-13]. The different results obtained for different roots directions are shown on Fig 3.

It was found that roots gravitropic reaction was negative in first case and it was slowed essentially in the second one. In third case it was usual. So for the combined magnetic field the model for cyclotron resonance of ions is preferred because of the absence of any biological effect in some directions.

The other effect - the dependence of biological effect on the method of observation of gravistimulation may be easily explained in frames of this model. While observing the gravitation reaction on wet plane when the roots touched the plane with all their length we changed the direction of ions moving and so changed the biological effect.

The only objection from this model was the fact that the free path of $\mathrm{Ca}^{2+}$ ions was small. We estimated it. The average thermal velocity for $\mathrm{Ca}^{2+}$ ions was equal to $200 \mathrm{~m} / \mathrm{s}$, time between collisions was of the order $10^{-9} \mathrm{~s}$. So the free path was equal to $2 \cdot 10^{-7} \mathrm{~m}(200 \mathrm{~nm})$. As the distance between the $\mathrm{Ca}^{2+}$ channels was of the order 5-10 $\mathrm{nm}$ [21] the ion had time for 
Primary physical mechanism of different magnetic fields action on roots...

interaction with many channels. If the free path might be increased by $5-50$ times, then any objection about the possibility of cyclotron resonance could be overcome because its length will approach the dimension of plant's cell. In the case with static or alternative magnetic fields we didn't need longer free path. Obtained free path is quite enough. We shall notice here that for $\mathrm{H}^{+}$ions the average velocity and so the free path was by 7 times more than for $\mathrm{Ca}^{2+}$ ions.

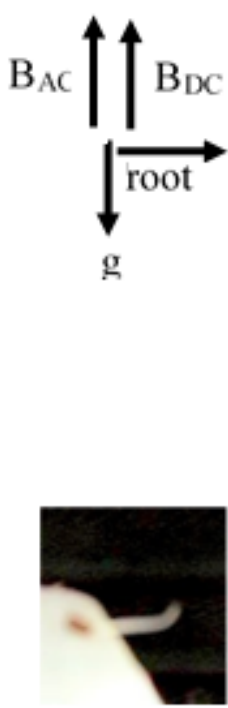

1
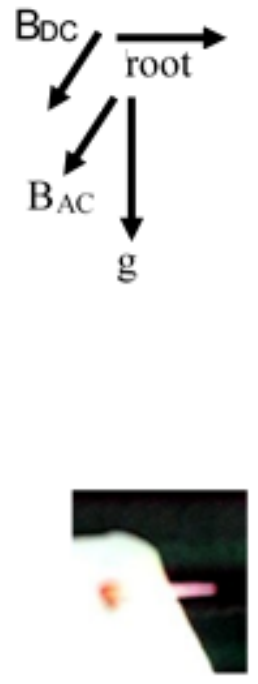

2
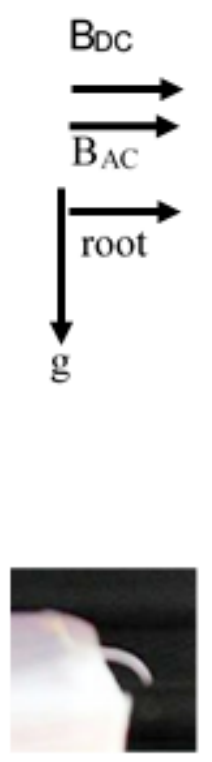

3

Fig.3. Different biological effect for different directions of combined magnetic field. Here $\mathrm{B}_{\mathrm{DC}}$ is the induction of static magnetic field component; $\mathrm{B}_{\mathrm{AC}}$ is the induction of alternative magnetic field component. They are parallel to each other. Combined magnetic field was parallel to the gravitation vector, the roots were located perpendicular to gravity and combined magnetic field vector (1); combined magnetic field was perpendicular to the gravitation vector and roots were located perpendicular to combined magnetic field and gravity (2); combined magnetic field was perpendicular to the gravity and roots were located parallel to combined magnetic field (3). The primary direction of roots always lays in the horizontal plane and is directed perpendicular to the acceleration due to gravity g. On the photos the gravitropic reaction of roots was fixed after 2 hours' treatment in different combined magnetic fields. The orientation of roots and corresponding the photo combined magnetic fields components relatively gravity vector $g$ were showed above each photo. Here results were shown for cress' roots. Analogous results were obtained for pea' roots and maize ones. All results were obtained for the frequencies of alternative magnetic field component tuned to the cyclotron frequency of $\mathrm{Ca}^{2+}$ ions in the static magnetic field $\mathrm{B}_{\mathrm{DC}}$.

The other effect that we couldn't throw away was the fact that the amyloplasts were the starch grains (porous piezoelectric), and thus they are piezoelectric particles. While they are pressed to membrane the grains might polarize and create the electric field near themselves. As the direction of created dipole of the starch grain near the membrane wasn't determined it had to rotate and aspire to be parallel to the direction of electric field even in the contrary to the gravity. The created electric field is alternative one and had the frequency of alternative component of combined magnetic field. So in combined magnetic field the dipole had to change its direction with the changing the direction of alternative magnetic field. Besides the dipole moves in combined magnetic field and creates electric field. That should to lead to electromagnetic field generation from the dipole. So the grains lost the energy and gravitropic reaction may be changed. The resonance had to take place when the frequency generated by electric dipole coincided with the frequency of alternative component of combined magnetic 
field. But this frequency had nothing with the cyclotron frequencies of ions observed in experiment. The advantage of this model was in the absence of necessity of long free path for particles. This model couldn't explain the threshold for the dependence of biological effect probability on the induction of magnetic field. But the direction of dipoles relatively combined magnetic field was also important. The generation of electromagnetic noise from plants was observed by us in [9].

The third independent physic-chemical mechanism is connected with our last experimental work [18]. It is based on the result that the hydronium ions took immediate part in the gravitropic reaction. Though there was no any negative gravitropic reaction for these ions (it was only the essential decreasing of the gravitropic reaction) the peak for $\mathrm{H}_{3} \mathrm{O}^{+}$ions was well observed.

We also observed the increasing of concentration of $\mathrm{H}+$ ions ( $\mathrm{pH}$ measurements) during treatment of the pure water in combined magnetic field alternative component of which was tuned to the cyclotron frequency of hydronium ions. According to the hypothesis of Del Giudice [16] the free path for ions in the water near the membrane was much longer than in usual because of domain structure of this water and ion might jump between the domains. The change in the $\mathrm{H}_{3} \mathrm{O}^{+}$and $\mathrm{H}^{+}$ions concentration that took place at the frequency of alternative magnetic field equal to the cyclotron frequency of the $\mathrm{H}_{3} \mathrm{O}^{+}$ions led to the change of other water characteristics It might lead to the changes of stretching and it might be different in different parts of the root. So it might lead both to decreasing of gravitropic reaction and to negative gravitropic reaction.

As the peaks of $\mathrm{Ca}^{2+}$ ions and hydronium ions were located very close between themselves the effects might be mixed. All the ions including the ions of metals may get to the EZ zone near membrane (the zone of structured water) but it is not clear whether they will have the long free path in that zone or only water components will have the long free path in that zone.

The measurements of conductivity of pure and clean water with the fixed concentrations of $\mathrm{Ca}^{2+}$ ions can give the answer on this question.

\section{CONCLUSIONS}

Three physical primary mechanisms were proposed in the work. The first one was preferable (this was the mechanism of action of magnetic field on ions).

It could explain the presence of the threshold in the dependence of probability of biological effect (changes in gravitropic and growing reactions in our case) on the induction of static magnetic field and the same effect in the alternative magnetic field (the threshold character of the changes in gravitropic reaction on amplitude of alternative magnetic field induction).

This mechanism was responsible for the resonance interaction of combined magnetic field alternative component of which was tuned for the cyclotron frequency of the ion (or for the magnetic moment of the ion that was one and the same). It could explain also all direction dependencies of biological effect. The only objection that the free path of the ion was too short for existence of ion cyclotron resonance might be overcame by the hypothesis that in EZ-water near the membrane the free path of any ions (not only hydronium) was much longer. But we couldn't exclude the other two primary mechanisms. Beside the third one was the first mechanism fitted to the water.

\section{REFERENCES}

1. Bogatina N.I., Litvin V.M., Travkin M.P. Possible mechanisms of action of magnetic, gravitropic and electric fields on biological objects, the analogies in their action // Electronic treatment of materials. 1986. No 1. P. 64-67. 
Primary physical mechanism of different magnetic fields action on roots...

2. Богатина Н.И., Веркин Б.И., Кулабухов В.Н. [и др.] Определение порога чувствительности проростков и корней пшеницы к величине магнитного поля // Физиология растений. 1979. Т.26, №3. C. $620-625$.

3. Merkis A.I. Geotropic reaction of plants // Vil'nyus. 1973.

4. Богатина Н.И., Шейкина Н.В., Кордюм Е.Л. Изменения гравитропической реакции, вызванные постоянным магнитным полем // Біофізичний вісник. 2006. №17(1). С.78- 82.

5. Богатина Н.И., Шейкина Н.В. Влияние переменного магнитного поля на гравитропическую реакцию растений при экранировании постоянной составляющей магнитного поля. Роль частот Шумана // Ученые записки Таврического национального университета им. В.И. Вернадского Серия «Биология, химия». 2013. Т.26, №3. С. 27 - 34. ISSN 1606-3716.

6. Богатина Н.И., Шейкина Н.В., Кордюм Е.Л. Влияние ориентации корней кресс-салата и кукурузы относительно комбинированного магнитного поля на изменение их гравитропической реакции. Эксперимент и новая гипотеза, механизм адаптации // Ученые записки Таврического национального университета им. В. И. Вернадского Серия «Биология, химия». 2013. Т. 25 (64), № 2. С. 16-30.

7. Bogatina N.I., Sheykina N.V., Kordjum E.L. Maize and cress roots orientation in combined magnetic field change roots gravitropic reaction response on its action. Experiment and new hypothesis . Adaptation mechanism //Proceedings of VI International Congress "Low and superlow magnetic fields and radiation in biology and medicine. 02-06 July 2012. Saint-Petersburg. P.73-82. ISBN 5-86456-007-3. Saint-Petersburg : VNLU. (in English).

8. Bogatina N.I., Sheykina N.V. Influence of different relative orientation of static and alternative magnetic fields and cress roots on their gravitropic reaction // Ученые записки Таврического национального университета им. В.И. Вернадского Серия «Биология, химия». 2014. Т.27, №1. С.24-28.

9. Шейкина Н.В., Богатина Н.И., Кордюм Е.Л. Влияние комбинированного магнитного поля на гравитропическую реакцию растений и спектр электромагнитного излучения, генерируемого ими // Радиофизика и электроника. 2005. Т.10, №2. - Р.331 - 335 .

10. Bogatina N.I., Sheykina N.V., Kordjum E.L. Activation of metal ions and biologically active compounds ions action by combined magnetic field // Proceedings of V1 International Congress "Low and superlow magnetic fields and irradiation in biology and medicine. 02-06 July 2012, Saint-Petersburg. P. 90-98. ISBN 5-86456-007-3. Saint-Petersburg : VNLU. (in English).

11. Богатина Н.И., Шейкина Н.В., Кордюм Е.Л., Карачевцев В.А. Гравитропическая реакция растений в комбинированном (постоянном и переменном) магнитном поле // Доповіді НАН України. 2002. № 4. C. $176-179$.

12. Kordyum E.L., Bogatina N.I., Kalinina Ya. M., Sheykina N.V. A weak combined magnetic field changes root gravitropism // Advances in Space Research. 2005. V. 36, №7. P. 1229 - 1236.

13. Кордюм Є.Л., Соболь М.А., Калініна Я.М., Богатина Н.І., Шейкіна Н.В. Біологічна дія комбінованого магнітного поля на гравітропічну реакцію кореня lepidium Sativum L.// Укр. ботан. журн. 2009. T.65, №1. C.141-157.

14. Vincze L., Szasz G., Liboff A. New theoretical treatment of ion resonance phenomena //, Bioelectromagnetics. 2006. V.29. P.380-386.

15. Bingi V.N. A primary physical mechanism of biological effects of weak magnetic fields // Biophysics. 2016. V.61, No1. P. 201-208.

16. Del Giudice E., Fleichmann H., Preparata G., Talpo G. On the "unreasonable"effects on ELF magnetic fields upon a system of ions// Bioelectromagnetics . 2002. V.23. P. 522-553.

17. Шейкина Н.В., Богатина Н.И., Кордюм Е.Л. Зависимость гравитропической реакции кресс-салата от амплитуды переменной составляющей комбинированного магнитного поля // Біофізичний Вісник (Вісник Харківського университету). 2007. Т.№18(1). Р. 78 - 90.

18. Bogatina N.I., Sheykina N.V. Role of Hydronium ions in biological effects of weak combined magnetic fields // Physics of Alive. 2014. T.21, №1-2. P. 43-45.

19. Grimaldi S., Lisi, A., Ledda M., D'Emilia E., Liboff A., Giuliani L., Foletti A. Weak-field H3O(+) ion cyclotron resonance alters water refractive index // Journal: Electromagnetic Biology and Medicine. 2016. 001R.2. P.1-24.

20. Bogatina N.I., Sheykina N.V. Effect of alternative magnetic field on plants gravitropic reaction under the conditions of absence of static components of magnetic field //X INTERNATIONAL CRIMEAN CONFERENCE «COSMOS AND BIOSPHERE». 23 - 28 September 2013. Koktebel. Crimea. Ukraine. (in English)

21. Сидоров А.В. Физиология внутриклеточной коммуникации . Минск: БГУ. 2008. 


\section{REFERENCES}

1. Bogatina, N.I., Litvin, V.M., Travkin, M.P. (1986.) Possible mechanisms of action of magnetic, gravitropic and electric fields on biological objects, the analogies in their action. Electronic treatment of materials, (1), 64-67.

2. Bogatina, N.I., Verkin, B.I., Kulabuhov, V.N. [et al.] (1979) Opredelenie poroga chuvstvitel'nosti prorostkov i kornej pshenicy k velichine magnitnogo polja. Fiziologija rastenij, (26, №3), 620-625. (in Russian)

3. Merkis, A.I. (1973) Geotropic reaction of plants. Vil'nyus. (in Russian)

4. Bogatina, N.I., Sheykina, N.V., Kordjum, E.L. (2006) Izmenenija gravitropicheskoj reakcii, vyzvannye postojannym magnitnym polem. Biofizichnij visnik, (17(1)), 78-82. (in Russian)

5. Bogatina, N.I., Sheykina, N.V. (2013) Vlijanie peremennogo magnitnogo polja na gravitropicheskuju reakciju rastenij pri jekranirovanii postojannoj sostavljajushhej magnitnogo polja. Rol' chastot Shumana. Uchenye zapiski Tavricheskogo nacional'nogo universiteta im. V.I. Vernadskogo Serija «Biologija, himija», (26, №3), 27 - 34. (in Russian)

6. Bogatina, N.I., Sheykina, N.V., Kordjum, E.L. (2012) Vlijanie orientacii kornej kress-salata i kukuruzy otnositel'no kombinirovannogo magnitnogo polja na izmenenie ih gravitropicheskoj reakcii. Jeksperiment $\mathrm{i}$ novaja gipoteza, mehanizm adaptacii. Uchenye zapiski Tavricheskogo nacional'nogo universiteta im. V. I. Vernadskogo Serija «Biologija, himija», (25, № 2), 16-30. (in Russian)

7. Bogatina, N.I., Sheykina, N.V., Kordjum, E.L. (2012) Maize and cress roots orientation in combined magnetic field change roots gravitropic reaction response on its action. Experiment and new hypothesis . Adaptation mechanism. Proceedings of V1 International Congress "Low and superlow magnetic fields and radiation in biology and medicine, Saint-Petersburg, 02-06 July 2012 (pp 73-82). ISBN 5-86456-007-3. Saint-Petersburg : VNLU.

8. Bogatina, N.I., Sheykina, N.V. (2014) Influence of different relative orientation of static and alternative magnetic fields and cress roots on their gravitropic reaction. Uchenye zapiski Tavricheskogo nacional'nogo universiteta im. V. I. Vernadskogo Serija «Biologija, himija», (27, №1), 24-28.

9. Sheykina, N.V., Bogatina, N.I., Kordjum, E.L. (2005) Vlijanie kombinirovannogo magnitnogo polja na gravitropicheskuju reakciju rastenij i spektr jelektromagnitnogo izluchenija, generiruemogo imi. Radiofizika $i$ jelektronika, (10, №2), 331 - 335. (in Russian)

10. Bogatina, N.I., Sheykina, N.V., Kordjum, E.L. (2012) Activation of metal ions and biologically active compounds ions action by combined magnetic field. Proceedings of V1 International Congress "Low and superlow magnetic fields and irradiation in biology and medicine, Saint-Petersburg, 02-06 July 2012 (9098). ISBN 5-86456-007-3. Saint-Petersburg : VNLU.

11. Bogatina, N.I., Sheykina, N.V., Kordjum, E.L., Karachevcev, V.A. (2002) Gravitropicheskaja reakcija rastenij v kombinirovannom (postojannom i peremennom) magnitnom pole. Dopovidi NAN Ukrä̈ni, (4), 176 - 179. (in Russian)

12. Kordyum, E.L., Bogatina, N.I., Kalinina, Ya. M., Sheykina, N.V. (2005) A weak combined magnetic field changes root gravitropism. Advances in Space Research,. (36, №7), 1229 - 1236.

13. Kordjum, E.L., Sobol', M.A., Kalinina, Ja.M., Bogatina, N.I., Sheykina, N.V. (2009) Biologichna dija kombinovanogo magnitnogo polja na gravitropichnu reakciju korenja lepidium Sativum L..Ukr. botan. zhurn., (65, №1), 141-157. (in Ukrainian)

14. Vincze, L., Szasz, G., Liboff, A. (2006) New theoretical treatment of ion resonance phenomena. Bioelectromagnetics, (29), 380-386.

15. Bingi, V.N. (2016) A primary physical mechanism of biological effects of weak magnetic fields. Biophysics, (61, No1). P. 201-208.

16. Del Giudice, E., Fleichmann, H., Preparata, G., Talpo, G. (2002) On the "unreasonable"effects on ELF magnetic fields upon a system of ions. Bioelectromagnetics, (23), 522-553.

17. Sheykina, N.V., Bogatina, N.I., Kordjum, E.L. (2007) Zavisimost' gravitropicheskoj reakcii kress-salata ot amplitudy peremennoj sostavljajushhej kombinirovannogo magnitnogo polja, Biofizichnij Visnik (Visnik Harkivs'kogo universitetu), (18(1)), 78 - 90. (in Russian)

18. Bogatina, N.I., Sheykina, N.V. (2014) Role of Hydronium ions in biological effects of weak combined magnetic fields. Physics of Alive, (21, №1-2), 43-45.

19. Grimaldi, S., Lisi, A., Ledda, M., D'Emilia, E., Liboff, A., Giuliani, L., Foletti, A. (2016) Weak-field H3O(+) ion cyclotron resonance alters water refractive index. Journal: Electromagnetic Biology and Medicine, (001R.2), 1-24.

20. Bogatina N.I., Sheykina N.V. (2013) Effect of alternative magnetic field on plants gravitropic reaction under the conditions of absence of static components of magnetic field. XINTERNATIONAL CRIMEAN CONFERENCE «COSMOS AND BIOSPHERE», 23 - 28 September 2013, Koktebel, Crimea, Ukraine. VNLU. (in English)

21. Sydorov, A.V. (2008) Fyzyolohyia vnutrykletochnoi kommunykatsyy. Mynsk: BHU. (in Russian) 